\title{
Applying Global Databases to Foresight for Energy and Land Use: The GCDB Method
}

\author{
Gilbert Ahamer \\ Senior Scientist, gilbert.ahamer@chello.at \\ Wegener Centre for Climate and Global Change, Graz University, Macherstrasse 15, 8047 Graz, Austria
}

\begin{abstract}
A

ny economy strongly depends on energy trends, which, as practice shows, are non-linear. This paper proposes an efficient method for predicting these trends. It is based upon a geo-referenced approach and combines a biosphere-energy model with a Global Change Data Base (GCDB). The advantage of the considered method over "pure modelling" lies in its heuristics, dealing with the real historical dynamics of techno-socio-economic systems. Newly emerging qualities and saturation effects will be better portrayed by the proposed method, which includes first and second derivatives. The novelty of the GCDB method

is in that it uses correlations of data series rather than data points. This allows for insights when contemplating swarms of data series and a heuristic examination of whether or not the widely-used hypothesis of path dependency in energy economics - and, more generally, in economic development is applicable.

The author believes that the application of the GCDB method will increase the credibility of conclusions based on the collected data, enrich the knowledge in the field of "growth theory», expand the knowledge base, and increase the efficiency of public policy related to climate change.
\end{abstract}

Keywords: energy foresight; global modelling; Global Change Data Base; scenarios; trends extrapolation; dynamics-as-usual scenario; biomass energy; land use change; saturation

Citation: Ahamer G. (2018) Applying Global Databases to Foresight for Energy and Land Use: The GCDB Method. Foresight and STI Governance, vol. 12, no 4, pp. 46-61. DOI: 10.17323/2500-2597.2018.4.46.61 


\section{Introduction: mapping energy trends from the system dynamics perspective}

Any economy puts a strong emphasis on the production of energy, and Kazakhstan (picked out as only one representative of an ex-Soviet country) might be a striking illustration of this (albeit transitory) state of development that all-too-often still includes nuclear energy with its unresolved safety issues [WNA, 2018], including polluting radioactive fallout [Ahamer, 2012]. Presently, mostly fossil fuels are produced on Kazakh territory, but limitations of availability and global climate protection treaties might well change the traditionally high increase in fossil fuel demand and hence could profoundly affect Kazakhstan's economic structure, which underlines its political influence in the Central Asian region [Gürgen et al., 1999, IMF, 2009].

In order to early identify and respond to such changes, attempts to "map" energy trends are undertaken (e.g., [IPCC, 2002; IIASA, WEC, 1998; Foster, Rosenzweig, 2003; Barro, 1991]). Traditional trend extrapolation follows the structure shown in Figure 1a at the left - be it linear, exponential or through other mathematical methods. For shorter periods, such an algorithm might be appropriate. However, if we want to extend projection periods to several decades, saturation effects and new qualities should be detectable, as shown in Figure $1 b$.

From the systems dynamics perspective of this article [Sterman, 2000], both these types of development are understood as principally foreseeable, because they may be predicted by increasingly stronger change rates, even if these are of initially minimal level ("weak signals" [Steinmüller, 2012; Hiltunen, 2006]. Hence, they often remain unperceived when principally understanding that reality is describable as a huge system of interconnected differential equations.

In future research terminology, other types of unexpected and more unlikely events are called "wildcards" [Nikolova, 2017; Walsh et al., 2015; Mehrabanfar, 2014], while a "tipping point" [Steinmüller, 2012] can principally be foreseen and explained from a systems dynamics viewpoint.

\section{Diverse understanding of foresight in literature}

While the term foresight is often used by companies for their immediate individual business prospects and for guidance on optimal investment strategies [Foresight Group, 2018] or for specific technological developments such as molecular nanotechnology [Foresight Institute, 2018; Drexler, 1986] or transport [Foresight Automotive, 2018], some scientists place more emphasis on the political consultation aspect of assessing multiple expert assessments on possible futures [Futurezone, 2013] or states' own procedures for planning their technology policies through technology foresight [BMBF, 2012; Austrian Parliament, 2018]. Numerous foresight companies [Horx, 2018; Z_Punkt, 2018] populate a dynamic market that suggests, discusses and assesses several diverse futures, rather than merely "judging correctly what is going to happen in the future and planning actions based on this knowledge", as suggested by mainstream dictionaries [Cambridge, 2018].

While for "pure" trend extrapolation we need values (let us call them $\mathrm{x}$ ), we will compute and contemplate the first and second derivatives $\left(\partial x\right.$ and $\left.\partial^{2} x\right)$ for facilitating the detection of saturation effects and new qualities. We consider all the cases $\left(x, \partial x\right.$ and $\left.\partial^{2} x\right)$ in details.

Until now, the basic foresight approaches for energy and land-use change (i.e. the "mapping" and "tracing" of energy issues into the future) have taken many forms. On the forthcoming pages, two such approaches are proposed: (1) classical maps of energy demand and potential energy supply and (2) plots of energyrelated structural variables against GNP/cap. We map the spatial and temporal patterns of supply and demand (and their driving forces). The combination of both approaches facilitates the "mapping" and "tracing" of dynamic structures [Ahamer, 2019] - in other words, foresight on a per-country level.

Geography as a spatial discipline (as distinct from e.g. physics, history or economics which rely more on temporal paradigms) proposes different views on reality from an idealised standpoint that no human being ever takes in practice (generalised bird's-eye view [Ahamer, 2019]). But this "borderline case"

Figure 1. A long-term analysis may as well unfold along wave-like steps of evolution: nonlinear futurology

a) Pure trend extrapolation

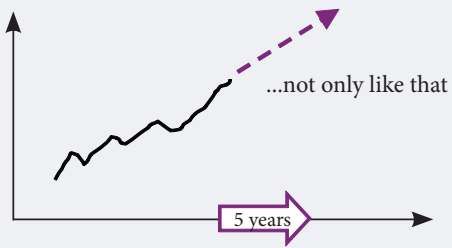

b) Saturation effects and new qualities

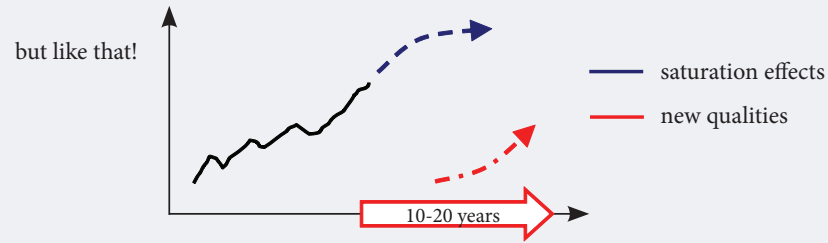


of a bird's-eye view permits the existing differences in perception among individuals to be overcome. Principally speaking, such a bridging of standpoints is needed in any civil society [Schmitz, 2009, p. 9; Schmitz, 2003, p. 21] in order to find - rather create - consensus solutions [Knizhnikov, 2018].

Using spatial and temporal maps, this article investigates the following issue: how much energy do we need globally and how can we cover that demand globally?

\section{Mapping spatial patterns of energy demand}

In the following, a simple formula shall be applied that has often been called "Kaya identity" [Kaya, 1990; Kaya et al., 1997; Rosa, Dietz, 2012], has largely been used in energy economics, climate protection and projections of $\mathrm{CO}_{2}$ emissions [IPCC, 2002; IIASA, 1998; WEC 2003]:

$\mathrm{CO}_{2}=\left(\mathrm{CO}_{2} / \mathrm{E}\right) \times(\mathrm{E} / \mathrm{GNP}) \times(\mathrm{GNP} /$ capita $) \times \mathrm{P},(1)$

where: $\mathrm{CO}_{2}$ - level of $\mathrm{CO}_{2}$ emissions

$\mathrm{E}-$ demand for energy (for a specific energy carrier)

GNP - gross national product (for a specific economic sector)

$\mathrm{P}$ - population.

Generally speaking and using terms of system analysis [Sterman, 2000; Bentley et al., 2004; Vester, von Hesler, 1980; Meadows et al., 1972] any complex (economic or other living) system tends to grow as a result of its inner structure [Heylighen, 1996; Chan, 2001]. Consequently, the growth rate of any (economic or other) system is closely determined by its inner (political, technological, social etc.) structure. We may hypothesise: if the system's structure remains the same, the growth rates are likely to be constant ${ }^{1}$. But in reality, each system changes during growth and alters its structure. This is the reason why each of the formula's quotients changes: it "walks along a path of development", and hence characterises the "emission scenarios".

This section shows gridded maps for each of the four magnitudes of which quotients appear in the formula (1) for the years 1990, 2025 and 2100: Population (Figure 2), Gross National Product GNP (Figure 3), demand of primary energy (Figure 4), shares of the fuels indexed by $\mathrm{f}$ (Figure 5). Additionally, the formula includes at the left end the respective emission factor to compute resulting $\mathrm{CO}_{2}$ emissions (Figure 6 and Figure 7 ). This $2.5^{\circ} \times 2.5^{\circ}$ grid for driving factors was designed for the "Combined Energy and Biosphere Model" CEBM, which projects IEA data ${ }^{2}$.

The maps in this section show the extensive magnitudes Pop, GNP, E, $\mathrm{CO}_{2}$. Quite visibly, these magnitudes are very suitable for classical geographic maps which focus on spatial structures. Among others, a shift in emphasis may be observed away from former centres such as Western Europe, Northern America, and Eastern Europe including CIS countries towards countries such as China and India, also partly Africa. This shift in components of $\mathrm{CO}_{2}$ emissions is in line with political and strategic shift, and generally in line with plausible evolutionary processes.

As already mentioned, the above maps in Figure 2 to Figure 7 show quantities that are measurable in numbers, monetary units, physical energy units - hence quantities pertaining to the material, physical world, often called extensive magnitudes because of their physical extension.

\section{Figure 2. Population in 1990, 2025, 2100 according to the CEBM scenario (1000 inhab.)}

a) 1990

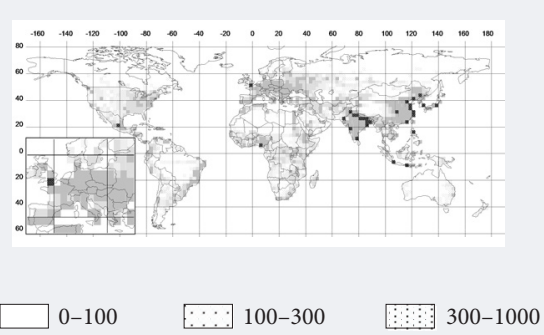

b) 2025

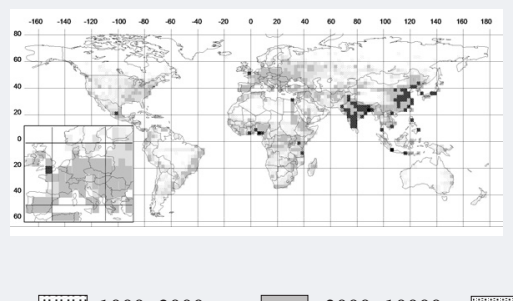

c) 2100

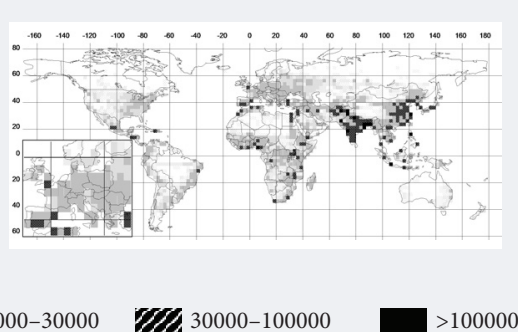

Note: All figures in this article are based on the author's own elaborations that are described in details at [Ahamer, 2019].

\footnotetext{
${ }^{1}$ In analogy to the well-known basic law in mechanics, attributed inter alia to Sir Isaac Newton: if no acceleration occurs, the velocity of a material body remains constant - this could thus be called the "Newtonian foresight paradigm".

2 The CEBM methodology was developed by the author during the year of his affiliation to IIASA [Ahamer, 1994].
} 


\section{Figure 3. Gross National Product GNP in 1990, 2025, 2100 according to the CEBM scenario (millions USD / year)}

a) 1990

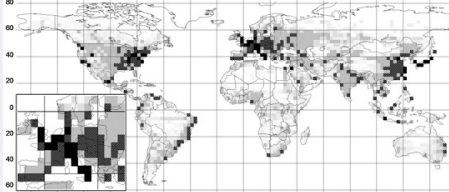

$\square$ 0-100 $\because 100-300 \quad 300-1000$ b) 2025

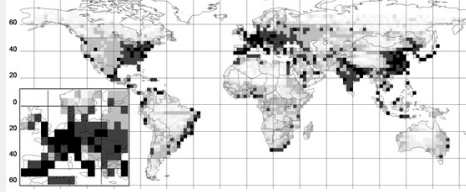

c) 2100

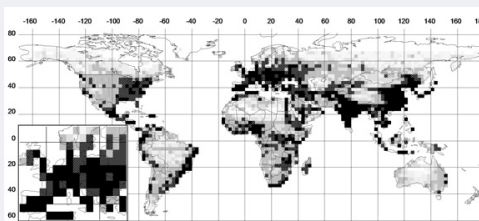

\section{Figure 4. Energy demand in 1990, 2025, 2100 according to the CEBM scenario (PJ/year)}

a) 1990

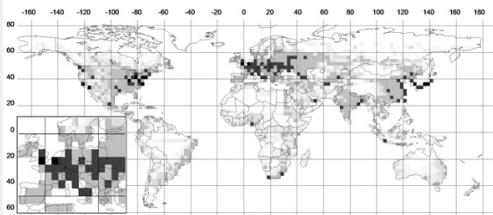

b) 2025

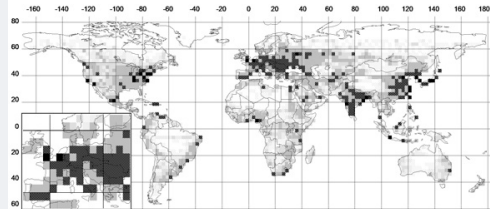

c) 2100

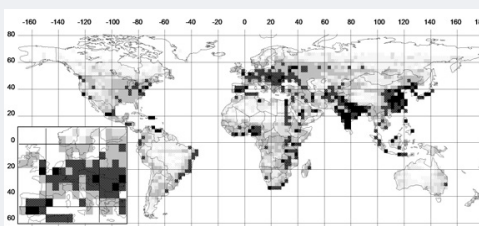

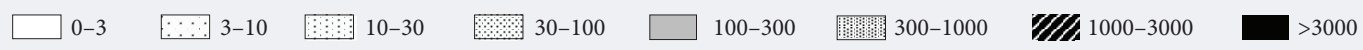

Figure 5. Various fuel shares in primary energy mix in 1990 according to the CEBM (\%/100)

a) Coal (1988)

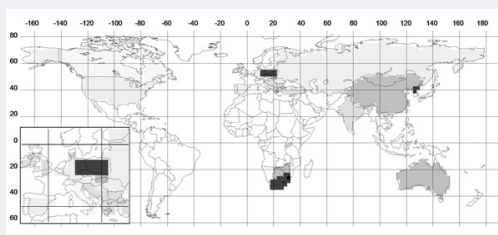

$\square-0.1$ b) Traditional biomass fuels

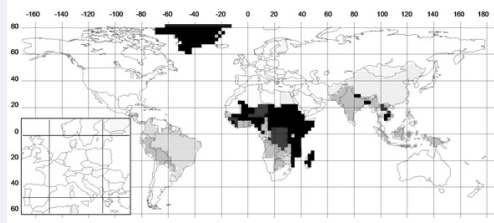

c) Non-carbon fuels (hydro + nuclear + geothermal)

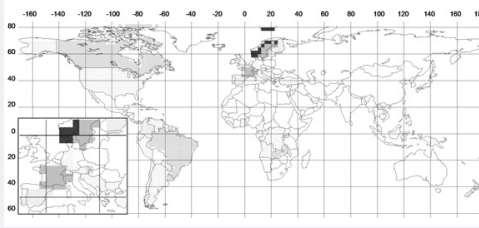


a) 1990

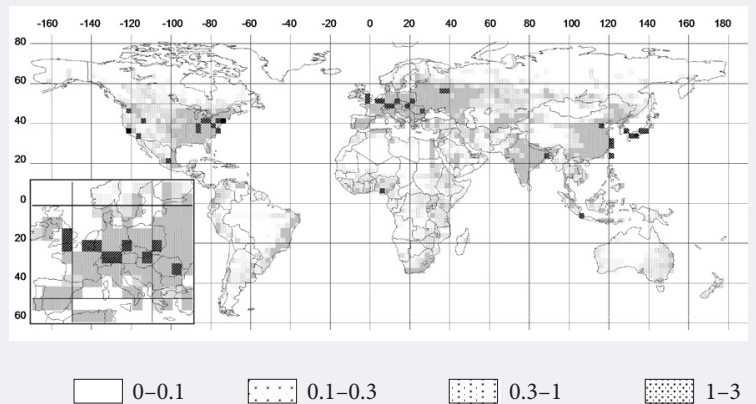

b) 2100 (valid for the biomass scenario and approximately for the base case scenario)

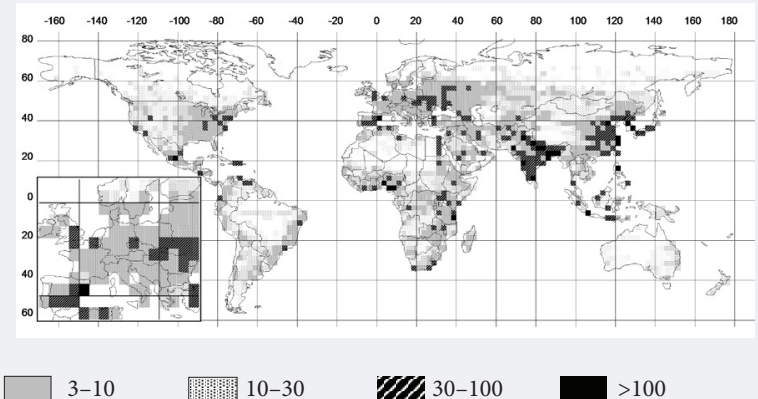

The modelling experience of the author [Ahamer, 2013, 2019] shows that extensive magnitudes are not likely to follow smooth paths (as has been suggested by the hypothesis of path dependency advocated by some branches of economics). Smooth paths and sizeable trends are more likely to be observed in systemic variables that are considered to describe a system's (here an energy system's) internal structure, inner interdependences and hence temporal dynamics. Based on this experience, the decision was made to shift the act of trend analysis from the realm of extensive magnitudes to the realm of intensive magnitudes. This decision is motivated both by pragmatic evidence (trends in intensive variables were visibly more stable) and by systemic deliberations (the software, culture, and organisational structure of a system is more stable than its imminent behaviour under annually changing outside pressures).

Therefore, the above formula and the methodology of projection does focus on the quotients of adjacent extensive factors, namely GNP/cap, E/GNP and $\mathrm{CO}_{2} / \mathrm{E}$, the so-called "drivers of $\mathrm{CO}_{2}$ emissions". Such quotients are called intensive magnitudes and describe systems and structures: the economic system, the

\section{Figure 8. CEnergy demand per capita in 1990 and 2100 (GJ/cap. per year)}

a) 1990

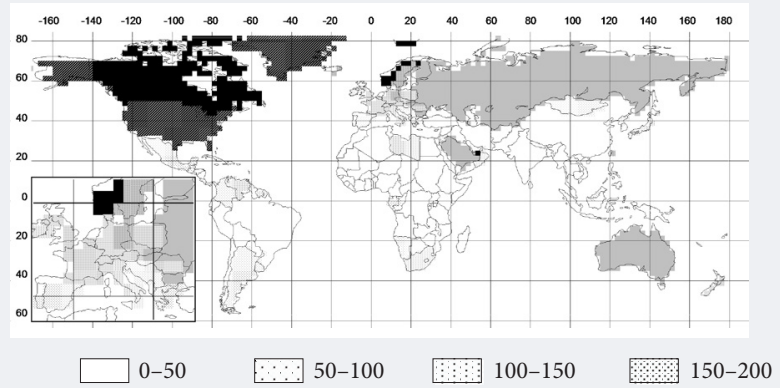

b) 2100 (according to the estimation of the CEBM)

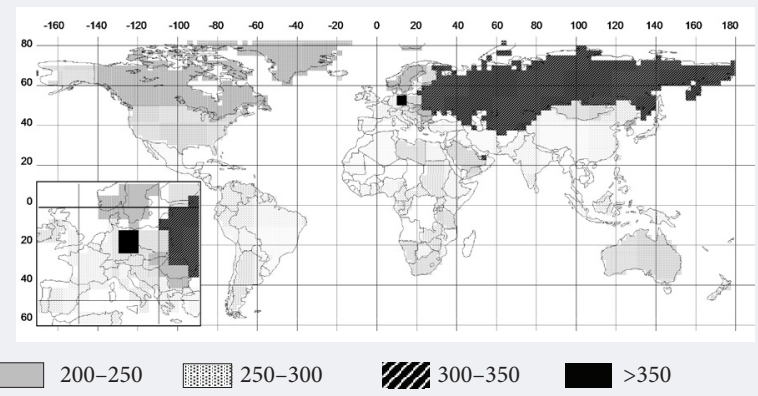

Figure 9. Fossil $\mathrm{CO}_{2}$ emissions per capita $\mathrm{CO}_{2}$ /cap for 1990 and 2100 ( $t$ C/cap per year)

a) 1990

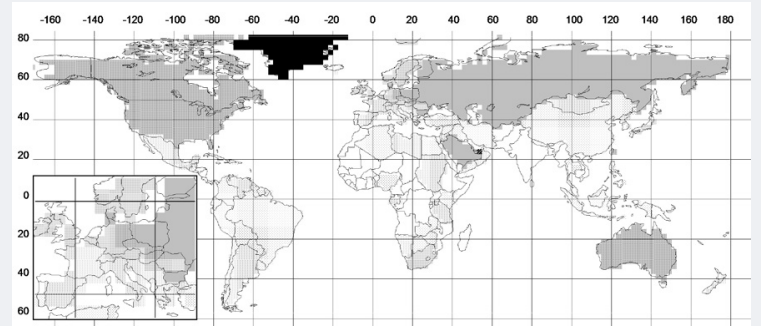

b) 2100 (according to the estimation of the CEBM)

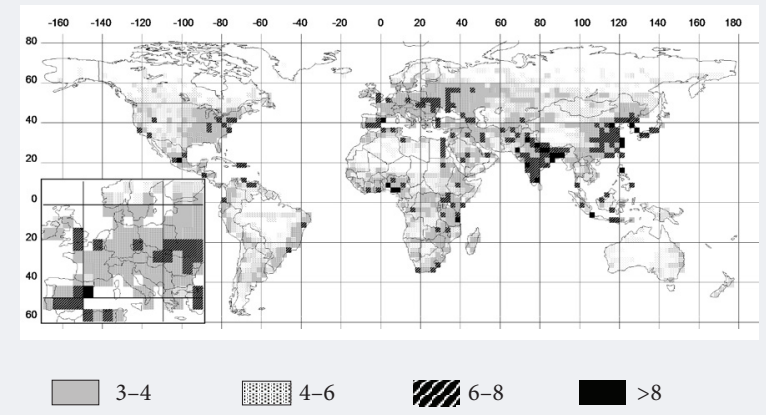




\section{Figure 10. Energy intensity (energy needed per economic output) E/GNP}

\section{for 1990 and 2100 (MJ per USD)}

a) 1990

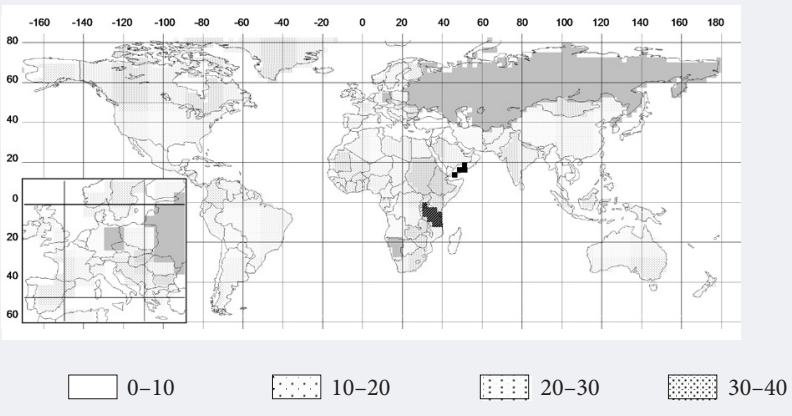

b) 2100 (according to the estimation of the CEBM)

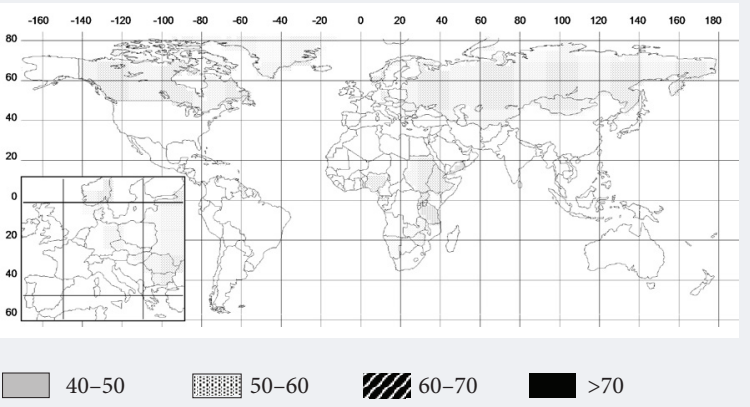

Figure 11. The economic level of a country (Gross National Product per capita) GNP/cap according to the CEBM for 1990, 2025 \& 2100 (under tight assumption of world-wide economic saturation) (1000 USD / cap.)

a) 1990

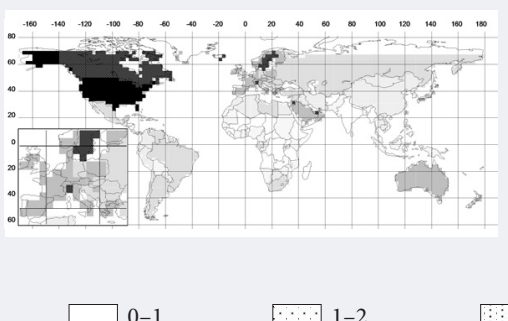

b) 2025

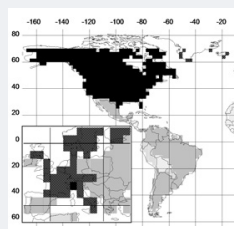

c) 2100

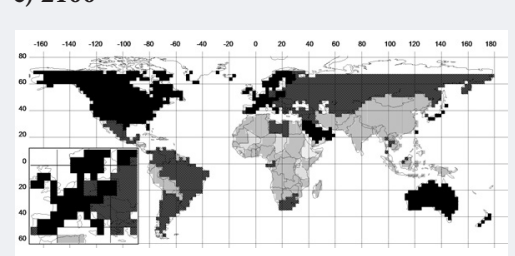

$\square 0-1 \quad \square{ }^{1-2}$
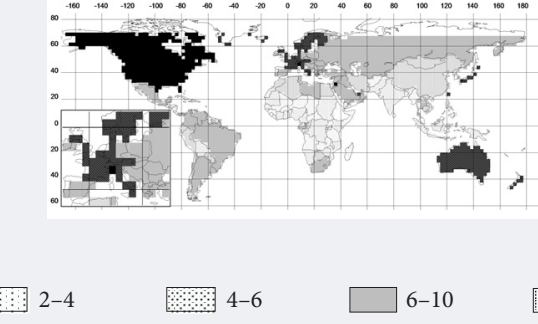

ZTA $15-20$ $>20$

energy system, the fuel structure - which are mostly characteristic of an entire country. Below we will display these maps that consequently have a per-country structure in the model used.

In addition to the absolute magnitudes $\left(\mathrm{CO}_{2}, \mathrm{E}, \mathrm{GNP}\right.$, Pop), the following figures show the relative magnitudes made up of the quotients of the neighbouring (and the subsequent) variables for the years 1990 and 2100: E/cap (Figure 8), $\mathrm{CO}_{2}$ /cap (Figure 9), E/GNP (Figure 10), GNP/cap (Figure 11).

It becomes visible from the uniform distribution of data within a country that the assumption of a homogenous energy system and economic system within a country was held to be reasonable. Therefore, the "granularity" of mapping changes from 2433 grid elements to 200 countries. An additional "degree of freedom" for mapping emerges from this systemic structure - this will be made use of in next sections. All components of the formula have been mapped in the above figures. The reader might have noticed that each of these parameters develops with a different dynamic and geographic pattern, might run into saturation or even reverse the direction of change from + to - or vice versa.

Geographic patterns of growth may show parallel growth in all countries or widening gaps between countries - this is a highly disputed question among economists [Basu, Weil, 1998] - regarding "growth theory"; regarding this question, a person may prefer to take a Neo-classical or Keynesian view [Barro, 1999]. Findings offered by literature include: political stability and democracy also promote economic growth [Barro, 1991, p. 432], not only technology [De Long, Summers, 1991], research \& development [Jones, Williams, 1998] and stable economic integration [Rivera, Romer, 1991, 1994; Devereux, Lapham, 1994]. Regression methods were widely used to analyse growth patterns in China and the USSR throughout the previous century [Ofer, 1987; Chow, 1993]. "Evolutionary economics" views developing economic structures [Bergh, Stagl, 2003, p. 290] and links them to institution building. In a sense, this recent scientific discipline can be seen as an application of Schumpeter's ideas [Hanusch, 1988].

In some studies [Grossman, Krueger, 1995, p. 370], environmental damage is reported to increase with GNP growth until a level of $9000 \$ /$ cap and then it decreases: this behaviour is referred to as the Environmental Kuznets Curve (EKC) [Foster, Rosenzweig, 2003]. According to the IMF [IMF, 2009], Kazakhstan's GDP/cap amounts to $6868 \$$ /a for 2007 - a good indication of upcoming improvement of fossil fuel-induced environmental damage... 
a) Population growth in all states.

(variable: POPI per 1990)

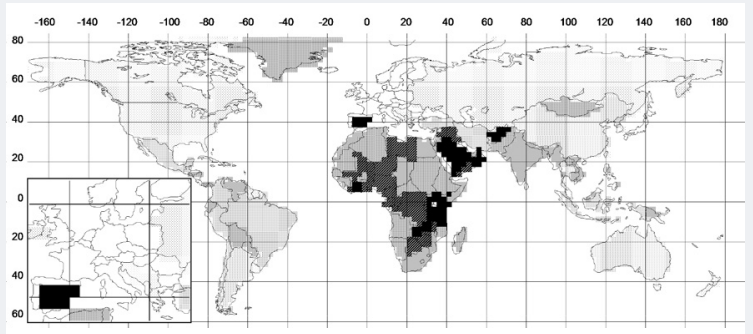

$0-0.5$ b) Growth of the Gross National Product per capita (GNP/cap), according to Penn World Tables

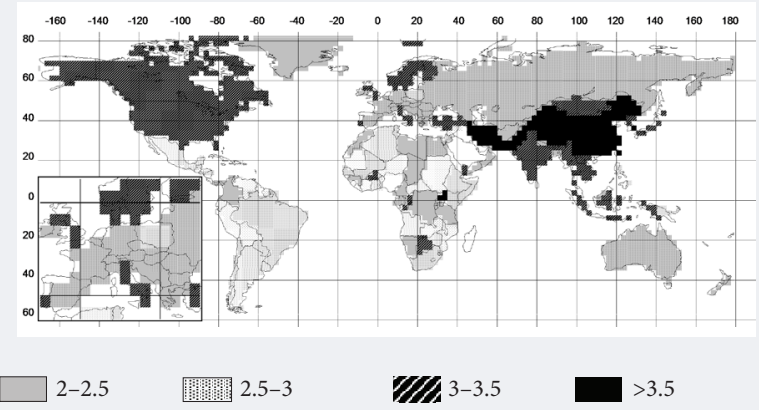

From the above deliberations, we can deduce that growth rates play a central role in describing the dynamics of a system, and thus in its future development. Consequently, we should concentrate on how to "map" them in a suitable manner.

As two examples, the growth rates for population (at left in Figure 12) and for GNP/cap (at right in Figure 12) are displayed as a traditional map, again serving to discern typical geographical patterns. However, interpretation will largely follow the lines of complex historic, economic and political "world wisdom" and does not easily open itself to simple dependencies on latitude, longitude or climate ${ }^{3}$.

At this point, our perspective opens from "patterns" to "the dynamics of patterns" - such as will be dealt with in later chapters.

\section{Mapping Spatial Patterns of Potential Energy Supply by Biomass}

One of the targets of the CEBM was to try to match global energy demand (series of figures after Figure 4 above) with the potential from biomass energy, because biomass energy is seen as a ready-to-use energy source that causes no net $\mathrm{CO}_{2}$ emissions. The following Figure 13 shows such spatial patterns of the maximum theoretical biomass potential, namely the annual growth of woody or herbaceous biomass on the natural or agricultural area of a grid cell [Ahamer, 1994; Ahamer, 2019]. By using only annual biomass growth (and not the entire biomass stocks), one basic criterion for sustainability appeared to be fulfilled. The global megatrend of agricultural efficiency improvement is likely to release pressure on arable land and to free up a certain amount of arable land for other targets such as energy production ${ }^{4}$. Therefore, an increased availability of land for biomass growth might be hypothesised in industrialised countries under favourable conditions.

The computation of the global potential of biomass for energy in Figure 13 uses five different principal strategies for land-use and plant growth (from above):

- as = energy use of agricultural biomass

- $\mathrm{av}=$ energy plantations on former natural areas

- $\mathrm{nv}=$ energy use of natural biomass at a plant age of 5 years $(\sim$ short rotation plants)

- nvn = energy use of natural biomass (= forestry)

- ap = energy plantation on former agricultural areas.

As Figure 13 shows, the global potential of biomass energy is unevenly distributed across the world and - more strikingly - the centres of biomass production do not coincide with the centres of energy demand. The result when comparing the geographic patterns of Figure 13 with Figure 4 is the huge need for transportation arising from such an extensive biomass-based energy strategy!

Figure 14 compares the global totals of energy supply (above three bars) with energy demand (below two bars): the main message is that the theoretical biomass potential equals the magnitude of the actual demand. In practice and after all necessary reductions from a theoretical potential, biomass alone as a fuel could never satisfy the needs of a global energy system - this is the second message of the CEBM results.

\footnotetext{
${ }^{3}$ Even if several authors have tried to deliver explanations that may seem overly simplistic to many readers [Landes, 2000].

${ }^{4}$ Similarly, a rise in forests with GDP/cap is reported by Foster \& Rosenzweig [Foster, Rosenzweig, 2003, p. 601].
} 


\section{Figure 13. Geographic distribution of the biomass fuel potentials for five biomass growth strategies:} as, av, nv, nvn, ap ( $\mathrm{g} C / \mathrm{m}^{2}$ per year)

a) Strategy as (energy use of agricultural biomass)

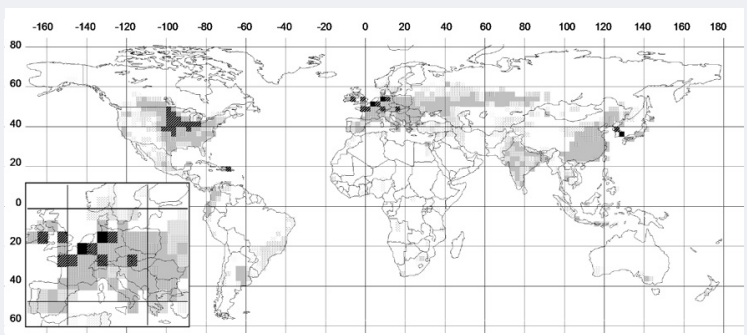

c) Strategy nv (energy use of natural biomass after plant age of 5 years)

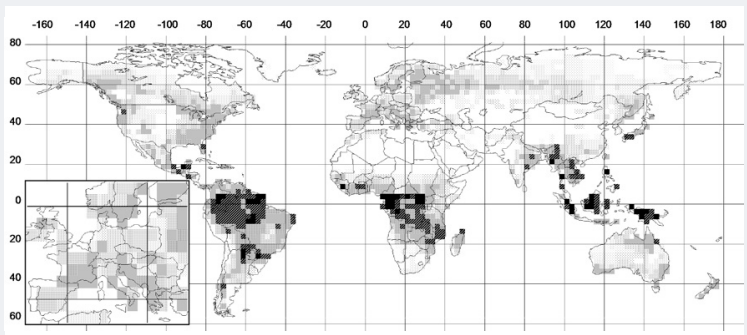

e) Strategy ap (energy plantations on former agricultural areas)

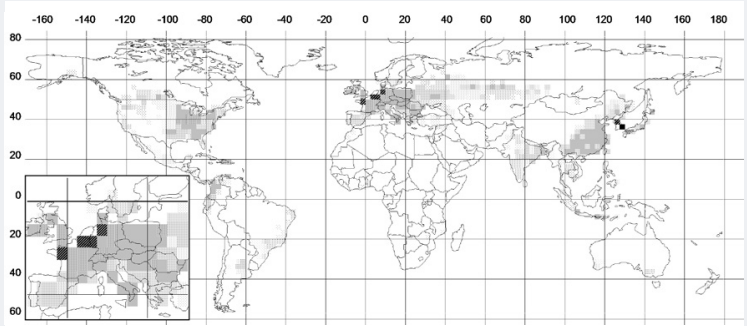

b) Strategy av (energy plantations on former natural areas)

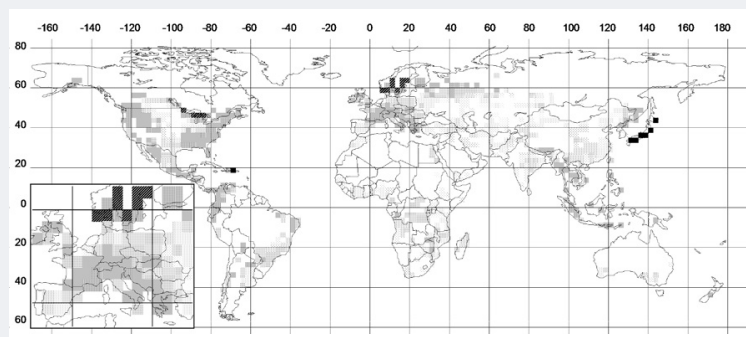

d) Strategy nvn (energy use of natural biomass at the natural plant age $=$ forestry)

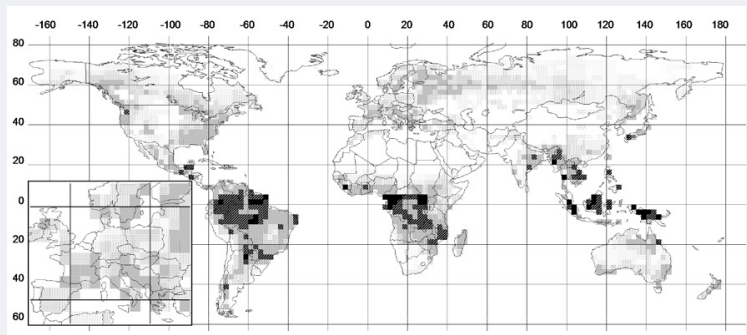

f) An assumption for the main global transport needs of biomass

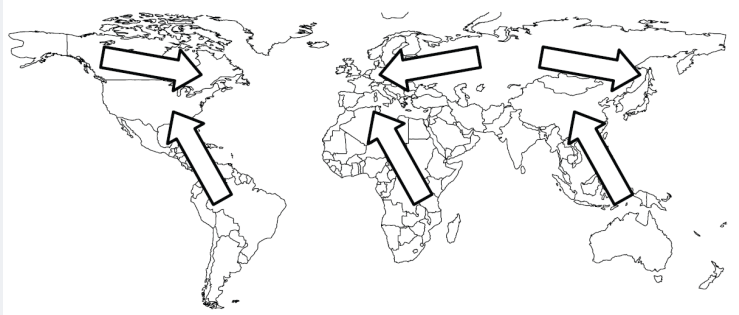

Legend for the maps (a-e)

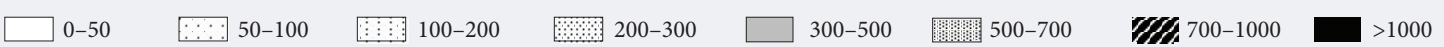

\section{Figure 14 . The global biomass potential compared to the global primary energy demand}

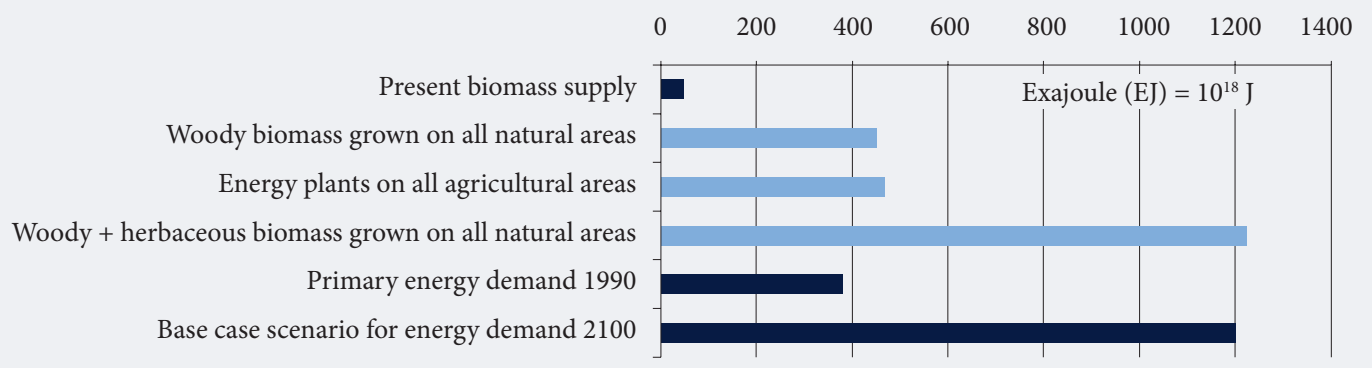

Source: simplified after [Ahamer, 2019] based on CEBM calculations (no conversion losses considered).. 


\section{Growth of energy demand: mapping temporal dynamics}

As mentioned, the aim of this article and the entire endeavour of creating the GCDB (Global Change Data Base) is to portray future development, i.e. develop a concrete quantitative foresight method. Further we will focus on explaining this "GCDB method".

Regarding a suitable strategy for visualising data and their dynamic development, one well-known option is to use the horizontal axis of a trend visualisation to illustrate the trend over time. Another, possibly less known option (e.g. also used for [Gapminder, 2018] or [IPCC, 2002, p. 125]) is to replace time with "economic level" (GNP/cap) because such a transformation of coordinates creates easily visible graphic structures - and because the economic path (even from some theoretical viewpoints) depends on the economic structure, which in turn depends on economic levels. Figure 15 gives an example of such a "mapping strategy".

What seems useful as a quantitative diagnostic tool is a sufficiently large, harmonised and geo-referenced database together with the means for producing a sufficient number of correlations between these data sets (not simply within the individual data). Then, the most stable and meaningful correlations shall be used as landmarks in a sufficiently plausible "map of techno-socio-economic evolution" (see the following figures with swarms of red lines). A subset of such "robust paths of development" will be interpreted based upon its potential to lead towards targets of sustainability vs. lead away from targets of sustainability. The most common example is engendered $\mathrm{CO}_{2}$ emissions, and therefore this will be focused on in this approach.

In order to give an example of the graphical appearance of the global data used by the GCDB method, trends for the driving forces of global change demonstrate the relative importance of effects on the climate caused by different aspects of the human impact on $\mathrm{CO}_{2}$ concentration (compare Figure 16 and [Altmann et al., 2013; Öttl et al., 2014]).

\section{The GCDB method: architecture and analytical tools}

The Global Change Data Base GCDB comprises over 2000 country-oriented variable sets (primary variables) for 100-200 countries ranging over several decades (mostly 1960-1991, depending on data availability) taken from the internationally accepted data stocks from international institutions such as the International Energy Agency IEA, the United Nations UN and its Statistical Office, the Food and Agriculture Organisation FAO, The World Bank WB, Human Development Indicators HDI, and World Development Indicators WDI (at left in Figure 17).

From these primary variables (mostly "extensive variables" according to the above definition), the GCDB is able to derive several thousand secondary variables such as indicators, intensities or rates (as examples of the above-defined "intensive variables"). The analytical tool of the GCDB (AT) is able to produce both quantitatively and graphically several thousand correlations between the abovementioned variable types (compare Figure 18), as explained in [Ahamer, 2013].

Diagrams are provided on a per-country basis, per continent, and for eleven world regions common to most global modelling, as used in energy economics [IPCC, 2002; GEA, 2012].

With the specific GCDB analytical tool, computations of country data and regional aggregates of sums, differences, products, quotients and derivatives of any GCDB variables are calculated along with correlation coefficients and plotted correlations of time series for several decades. For primarily graphical analysis, it combines the perspectives of time series analysis [Jones, 1995, p. 502; Islam et al., 2003, p. 151] and cross-correlation analysis (e.g. [Barro, 1991, 2001]) for explaining the levels, rates of change, and saturation effects in the field of economy, energy use and land use.

A considerable advantage of the proposed methodology - if combined with the concept of "path of development" (e.g. along rising GDP/cap.) - consists of the ability of the methodology to overcome the principal restriction of the reliability of projections to (following a rule of thumb) half of the period for which data exist. If ever the arrays of data for all countries were positioned near to a common path (which is the very criterion to be checked), then the basis of expansion into a likely future path stretches over "states from very poor to very rich" which is a substantially larger information basis than "states during some decades". Another advantage is that the $1^{\text {st }}$ and $2^{\text {nd }}$ derivatives of data series can be expected to exclude a number of flaws negatively affecting statistical analysability.

Until a recent literature check, no such methodology had been found until recently in scientific journals with the 15 highest impact factors ${ }^{5}$ in the fields of economy and energy. Furthermore, stable trends representing "paths of development" are identified and used to build a more complete picture of evolutionary patterns.

\footnotetext{
Among which are: Journal of Economic Literature, Quarterly Journal of Economics, American Economic Review, Ecological Economics, Econometrica, Economic Policy, Economic Geography, Economy and Society, Energy, Energy Economics, Journal of Financial Economics, Journal of Political Economy, NBER Macroeconomic Annals, Social Indicators Research. For the explanation of the 'ISI impact factor', see http://isiwebofknowledge.com/.
} 


\section{Figure 15. The growth rate of the final energy demand as a function of GNP/cap (\%)}

a)

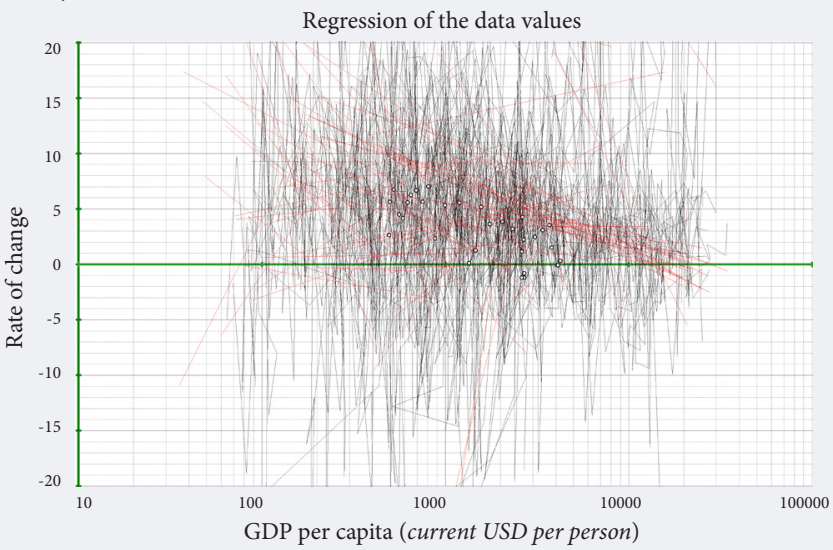

b)

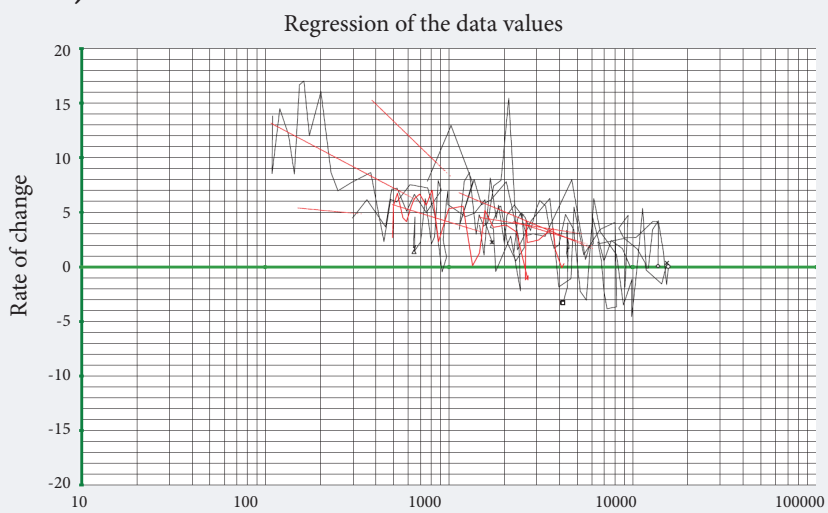

GDP per capita (current USD per person)

\section{Legend to diagram $(b)$}

\begin{tabular}{|c|c|}
\hline$\square$ & Soviet Union \\
\hline$\triangle$ & Africa \\
\hline * & Asia \\
\hline$x$ & Europe \\
\hline-0 & Northern and Central America \\
\hline$\diamond$ & Oceania \\
\hline & South America \\
\hline & World \\
\hline & Logarithmic (Soviet Union) \\
\hline & Logarithmic (Africa) \\
\hline & Logarithmic (Asia) \\
\hline & Logarithmic (Europe) \\
\hline & Logarithmic (Northern and Central Amer \\
\hline & Logarithmic (Oceania) \\
\hline & Logarithmic (South America) \\
\hline & Logarithmic (World) \\
\hline
\end{tabular}

\section{c)}

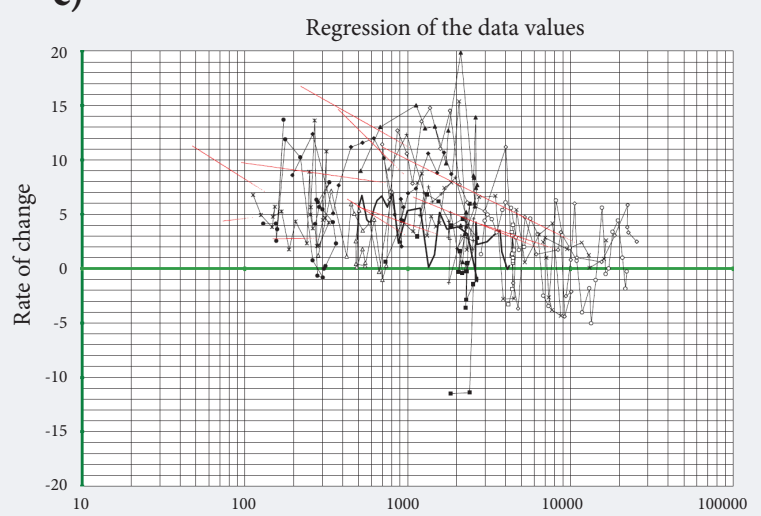

GDP per capita (current USD per person)

\section{Legend to diagram $(c)$}

World

- North America

$+\quad$ Latin America and Caribbean

$\times \quad$ Western Europe

- Central and East Europe

$\square$ Former Soviet Union

1 Middle East and North Africa

$\Delta \quad$ Sub-Saharan Africa

- Centrally Planned Asia

* South Asia

Other Pacific Asia

$\checkmark \quad$ Pacific OECD

Logarithmic (World)

Logarithmic (North America)

Logarithmic (Latin America and Caribbean)

Logarithmic (Western Europe)

Logarithmic (Central and East Europe)

Logarithmic (Former Soviet Union)

Logarithmic (Middle East and North Africa)

Logarithmic (Sub-Saharan Africa)

Logarithmic (Centrally Planned Asia)

Logarithmic (South Asia)

Logarithmic (Other Pacific Asia)

Logarithmic (Pacific OECD)

Note: Each black graph represents one country for duration of some three decades. For reducing the volatility of information visualized, a trend line is computed (in red). One red line thus means the trend of one single state (at left), of one continent (centre) and of one region (at right). 


\section{Figure 16. Dynamics of energy demand per capita}
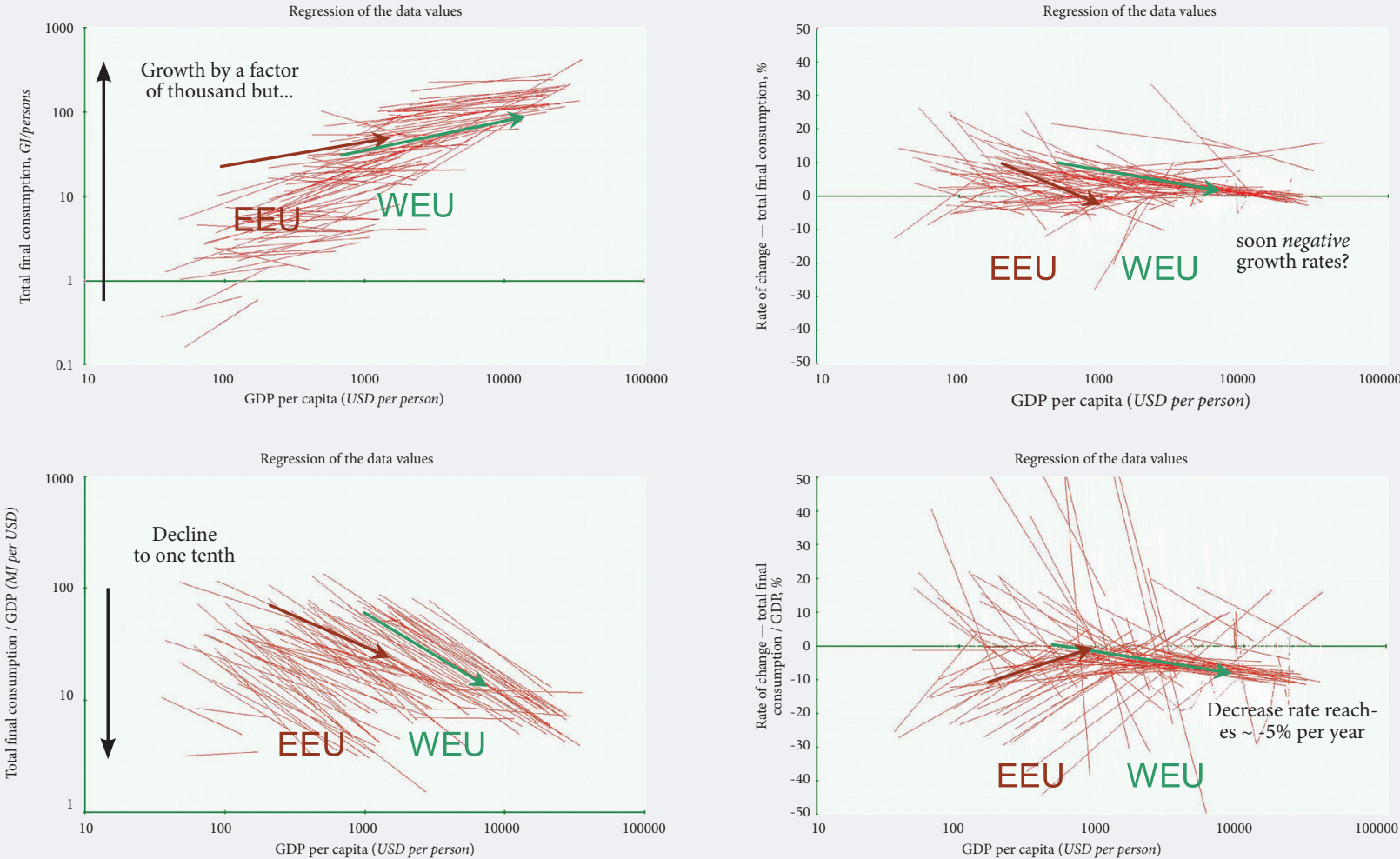

Note: Energy demand per capita is still rising worldwide (above left), but its already decreasing growth rate is starting to touch zero (above right) when plotted for all single countries as a function of economic level (Gross Domestic Product per capita = GDP/cap). This trend suggests a transition in the global energy system. Similarly, energy demand per GDP (= energy intensity) is strongly declining worldwide (below left) and additionally its growth rate is starting to decrease strongly (below right). .

Legend: $\mathrm{WEU}=$ Western Europe; EEU = Central \& Eastern Europe without Russia.

Source: [Ahamer, 2015].

\section{Figure 17. Data flow scheme for the "Global Change Data Base" GCDB}

Data sources
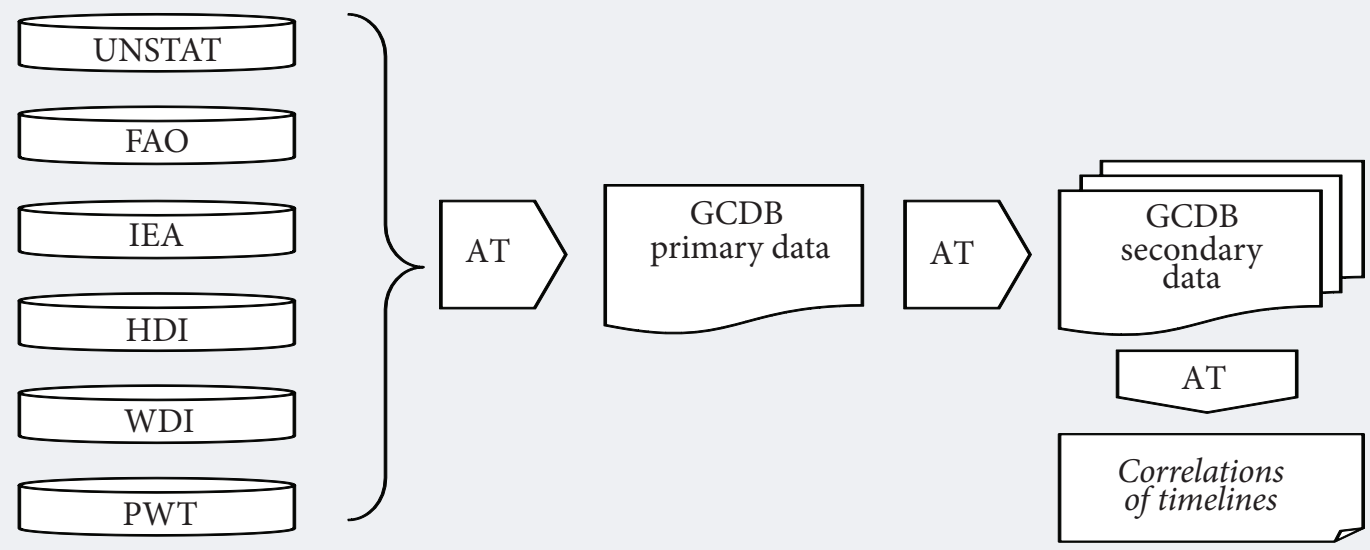

Note: For the details on abbreviation see text. At left — internationally compatible data sources. These data are topographically harmonised by the analytical tool (AT). By their mathematical combination, the AT computes a greater multitude of secondary data that are able to be correlated and then displayed graphically in order to detect so-called "paths of development" as hypothesised by some growth theories.

Source: [Ahamer, 2013]. 


\section{Figure 18. First attempts for spatio-temporal maps}
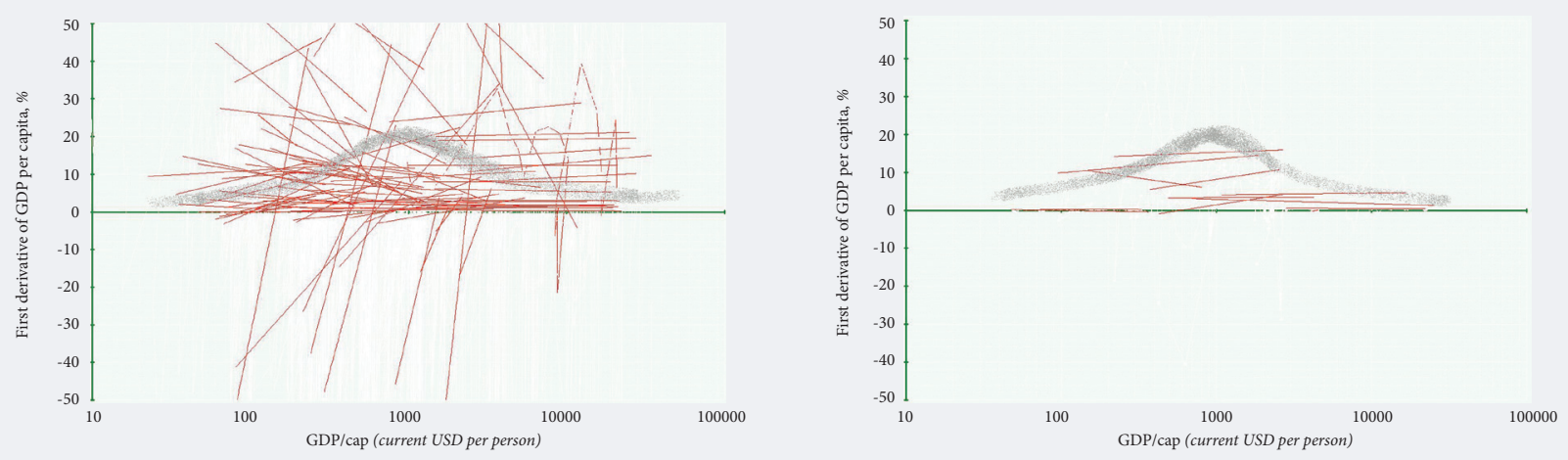

Note: Relative growth of GDP per capita is plotted against GDP/cap for an average of three decades for all countries (at left), and aggregated into 11 regions [Ahamer, 2019]. Grey sprayed-on colour hypothesises elevated growth rates of middle-income countries as compared to countries with high or low income; readily compatible with saturation growth curves (compatible in principle with [Korotayev, Zinkina, 2014]).

Global Climate Change is mainly driven by $\mathrm{CO}_{2}$ emissions [IPCC, 2001, 2014] which in turn are driven by economic, industrial and energy supply structures. The underlying evolutionary changes in these structures act as decisive driving forces for Global Change - and these driving forces are quantified.

Until now, the method of projecting the present condition of the socio-economic state has been widely used [Ang, Liu, 2000, p. 538]. However, the parameter "changes in rates of change" has not yet been sufficiently studied in order to yield well-founded information on likely deviations from a "business-asusual" path of development. Such deviations are likely to occur as crucial results from the internal system structure of the global techno-socio-economic system.

In this approach, the primary source of knowledge is the (intersubjectively re-examinable) "reality" (in the form of data describing reality) and not "model results" (or even prescriptions derived from preconceived models of reality as it is supposed to be, from whatever scientific school they might stem $)^{6}$. Therefore, information on correlations or changes in directions of development are based on data (from past decades), not on pre-conceived convictions laid down in world models. Interpretation (after having analysed using the GCDB tools) is up to the reader.

The methodology itself consists of analysing the "path locus" of all countries' time series and the texture, slope and twist of this array of curves including state-of-the-art statistical analysis.

The "main formula" of the GCDB approach for energy-related $\mathrm{CO}_{2}$ emissions is based on the abovementioned IPAT or Kaya identity [Kaya, 1990; Kaya et al., 1997; Rosa, Dietz, 2012], which in here enlarged by one quotient distinguishing primary and final energy ${ }^{7}$. It reads:

$\mathrm{CO}_{2}=\left(\mathrm{CO}_{2} / \mathrm{E}_{\mathrm{p}}\right) \mathrm{x}\left(\mathrm{E}_{\mathrm{p}} / \mathrm{E}_{\mathrm{f}}\right) \mathrm{x}\left(\mathrm{E}_{\mathrm{f}} / \mathrm{GDP}\right) \mathrm{x}(\mathrm{GDP} /$ capita $) \times$ Population

where: $\mathrm{CO}_{2} \quad-$ level of $\mathrm{CO}_{2}$ emissions (for a specific fuel and sector)

$\mathrm{E}_{\mathrm{p}} \quad$ - demand for primary energy (for a specific fuel and sector)

$\mathrm{E}_{\mathrm{f}} \quad$ - demand for final energy (for a specific fuel and sector)

GDP - gross national product (in a specific economic sector)

P - population.

Please note: for land use change-related $\mathrm{CO}_{2}$ emissions, a similar system structure is developed where the area takes the place of energy and the crop type takes the place of the fuel.

Types of variables describing the dynamics of the global evolutionary system (mostly as a function of GDP/cap), are depicted in Table 1, while hierarchy of indicators for the considered methodology presented in Table 2.

The IT methodology consists of (i) computing, (ii) statistically analysing and (iii) graphically depicting all forms of all types of variables of the GCDB, mostly following the "main formula".

When implementing the abovementioned main formula, harmonisation of different sectoral catalogues (e.g. between IEA and SNA statistics) must be performed; all remaining amounts must be interpreted with sufficient caution based on earlier experiences in national environmental accounting, especially

\footnotetext{
${ }^{6}$ Just as in the tradition of Galileo Galilei; who, for instance, urged contemporary cardinals to look through his telescope onto the astronomic reality supporting his worldview [Galilei, 2002].

For yet more detailed notation see [Ahamer, 2013, p. 373].
} 
1. Agriculture

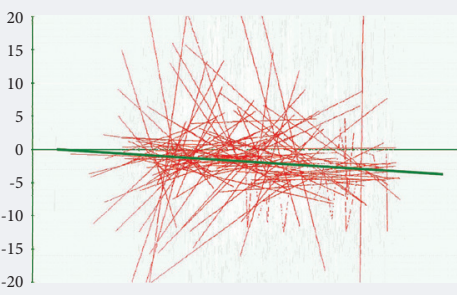

4. Electricity, gas, water

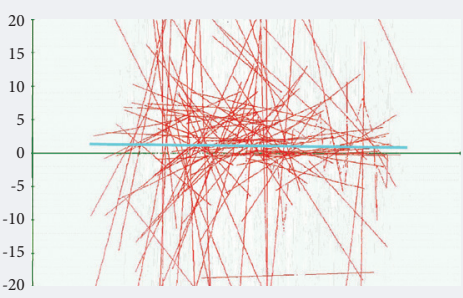

7. Transport and communication

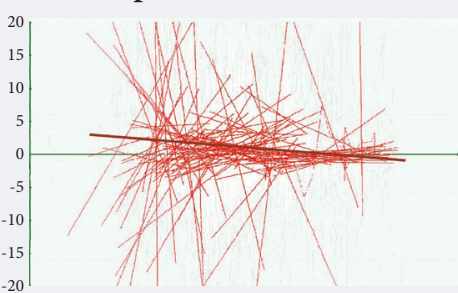

2. Mining

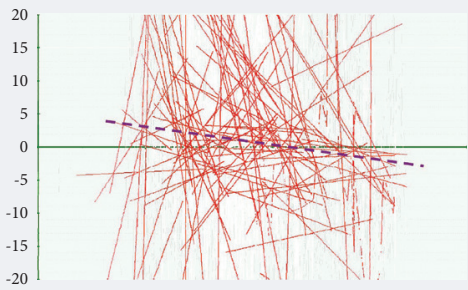

5. Construction

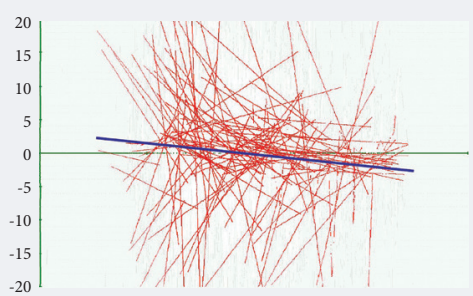

8. Finance and insurance

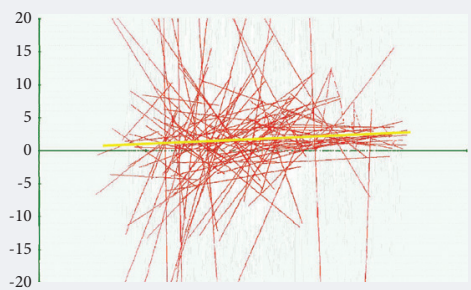

3. Manufacturing

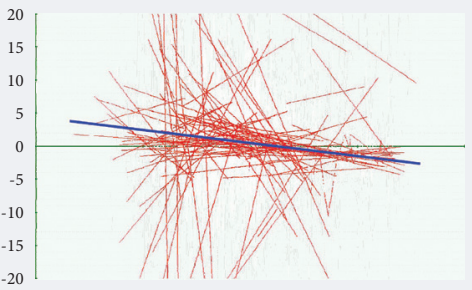

6. Commerce

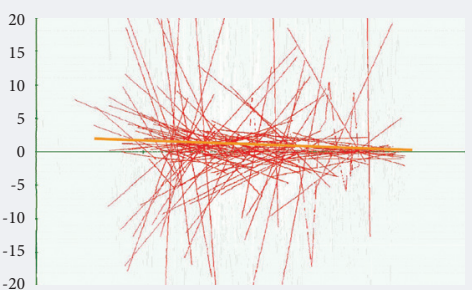

9. Community and social service

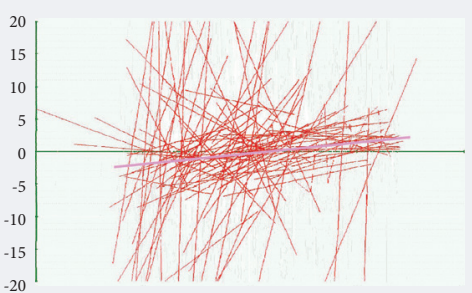

Legend: see Figure 18; vertical axis ranges from $-20 \% / \mathrm{a}$ to $+20 \% / \mathrm{a}$. Values above the green (zero) line mean growth; below mean decline.

regarding transportation and household [Schipper et al., 2000]. For this endeavour, the meaning of "sectoral intensity" will sometimes need to be handled cautiously as a proxy variable for relative shifts in "attention" or "attribution of values". The proposed method takes into account the "decomposition method" approaches [Schipper et al., 2000, p. 22] as having high merit in attributing percentages of driving forces to the "decarbonisation effect", "intensity effect", "rebound effect" and other partial movements of the interconnected socio-economic meta-structures.

\section{Conclusion}

Applying the GCDB method for forecasting presumes a number of implications for science and society. Further strengthening of understanding and corroborating the various, often contradictory developmental theories will contribute to multicultural understanding among economic ideologies, including related university curricula such as "Global Studies" [Bader et al., 2013, 2014]. It will provide further background information for studies that are designing, assessing and monitoring national and global climate protection measures. Economic "growth literature" will be widened by the approach of

\section{Table 1. Variables describing the dynamics of the global evolutionary system}

\begin{tabular}{|l|l|}
\hline \multicolumn{1}{|c|}{ Variable } & \multicolumn{1}{c|}{ Description } \\
\hline Levels & Denoted by the "state vector" $\mathrm{x}$ in this text, per each country, as times series \\
\hline Rates of change & $\begin{array}{l}\text { First derivative of a state vector }: \partial \mathrm{x}, \text { compare Figure 19), including saturation levels } \\
\text { (cases where first derivatives tend towards zero) }\end{array}$ \\
\hline $\begin{array}{l}\text { Changes in the rates of } \\
\text { change }\end{array}$ & $\begin{array}{l}\text { Second derivative of a state vector: } \partial^{2} \mathrm{x}, \text { aimed at better detecting saturation and other } \\
\text { non-linear behaviour, including variability of all the above types (inter-country, inter- } \\
\text { region, inter-temporal. }\end{array}$ \\
\hline \multicolumn{2}{|l}{ Source: compiled by the author. } \\
\hline
\end{tabular}


Table 2. Hierarchy of indicators

\begin{tabular}{|l|l|l|l|}
\hline \multicolumn{1}{|c|}{ Category } & \multicolumn{1}{c|}{$\begin{array}{c}\text { Described } \\
\text { parameter }\end{array}$} & \multicolumn{1}{c|}{ Examples } & \multicolumn{1}{c|}{$\begin{array}{c}\text { Graphical } \\
\text { representation }\end{array}$} \\
\hline Extensive entities & Stocks, flows & Energy, population, area & Figure 2 to 7 \\
\hline Intensive entities & Structures & Quotients, indicators, energy intensities & Figure 8 to 11 \\
\hline Shares & Compositions & Sectoral GDP, fuel mix & Figure 19 \\
\hline Source: author. & & \\
\hline
\end{tabular}

phase-dependent relative impact of "growth factors" on GDP growth. The GCDB toolkit will contribute to the to-date tool boxes in scenario writing, as well as concrete interdisciplinary application of concepts of systems science and game theory.

Awareness of background picture of global trends, when comparing to the trajectory of the respective nation. Systems analysis approach becomes more concrete towards "Global Change". This underpins a clearer link between the practicability of declared climate protection targets and the realistic room for action, thus allowing a more profound assessment of the directions of action for national climate policy. This leads to increasing public awareness of the necessity to steer technological development for ecology and $\mathrm{CO}_{2}$ abatement.

From the above calculations, at first glance, we see that growth rates of global energy demand will decline. This result is stable with regard to all fuels: the peak of coal, oil and gas seems to be over soon - in this sequence of fuels. A suitable counterstrategy against this megatrend which threatens the economic basis of any countries, but especially of post-Soviet states such as Kazakhstan (also Russia and others), is to diversify - into biomass, solar and wind (compare [Ermolenko et al., 2017; Proskuryakova, Kovalev, 2015]) - and to explore such potentials by global information systems.

Summing up, the Global Change Data Base (GCDB) method is a suitable tool for detecting trends and changes in trends in the global energy system, thus for better understanding its global dynamic behaviour.

\section{References}

Ahamer G. (1994) Influence of an Enhanced Use of Biomass for Energy on the $\mathrm{CO}_{2}$ Concentration in the Atmosphere. International Journal of Global Energy Issues, vol. 6, no 1/2, pp. 112-131.

Ahamer G. (2012) Geo-Referenceable Model for the Transfer of Radioactive Fallout from Sediments to Plants. Water, Air, and Soil Pollution, vol. 223, no 5, pp. 2511-2524, DOI: 10.1007/s11270-011-1044-x.

Ahamer G. (2013) A Planet-Wide Information System. Campus-Wide Information Systems, vol. 30, no 5, pp. 369-378. DOI 10.1108/CWIS-08-2013-0032.

Ahamer G. (2015) Applying student-generated theories about global change and energy demand. International Journal of Information and Learning Technology, vol. 32, no 5, pp. 258-271. DOI 10.1108/IJILT-01-2015-0002.

Ahamer G. (2019) Mapping Global Dynamics. From Local Pollution to Global Evolution, Heidelberg, New York, Dordrecht, London: Springer.

Altmann M., Eisenreich S., Lehner D., Moser S., Neidl T., Rüscher V., Vogeler T. (2013) Global inequality and poverty in perspectives of geography. Multicultural Education \& Technology Journal, vol. 7, no 2/3, pp. 127-150.

Ang B.W., Liu F.L. (2000) A new energy decomposition method: Perfect in decomposition and consistent in aggregation. Energy, vol. 26, no 6, pp. 537-548.

Austrian Parliament (2018) Foresight and Technology Assessment: Monitoring of future themes for the Austrian Parliament, Vienna: Austrian Parliament. Available at: https://www.parlament.gv.at/SERV/FTA/, accessed 04.12.2018

Bader L., Bereuther T., Deutsch E., Edlinger J., Füreder S., Kaspar E., Köttstorfer M., Mautner C., Rossegger C., Samonig A., Samonig S., Schuster C., Witz G., Zotter V., Ahamer G. (2013) Quality Improvements in Curricula for Global Studies. Multicultural Education and Technologies Journal, vol. 7, no 2/3, pp. 113-126. DOI $10.1108 / 17504971311328035$.

Bader L., Bereuther T., Deutsch E., Edlinger J., Füreder S., Kaspar E., Köttstorfer M., Mautner C., Rossegger C., Samonig A., Samonig S., Schuster C., Witz G., Zotter V., Rozanov A., Ilyin V., Ahamer G. (2014) Multiparadigmatic Humanities: Curricula for Global Studies. International Journal of Humanities and Social Science, vol. 4, no 6, part 1, pp. 314-337.

Barro R.J. (1991) Economic Growth in a Cross Section of Countries. Quarterly Journal of Economics, vol. 106, no 2, pp. 407-443.

Barro R.J. (1999) Ramsey Meets Laibson in the Neoclassical Growth Model. Quarterly Journal of Economics, vol. 114, no 4, pp. 1125-1152.

Barro R.J. (2001) Human Capital and Growth. American Economic Review, vol. 91, no 5, pp. 12-17. 
Basu S., Weil D.N. (1998) Appropriate Technology and Growth. Quarterly Journal of Economics, vol. 113, no 4, pp. 1025-1054.

Bentley L.D., Dittman K.C., Whitten J.L. (2004) System analysis and design methods. Boston, MA: McGraw-Hill, Irwin.

Bergh J.C.J.M., Stagl S. (2003), Coevolution of economic behaviour and institutions - towards a theory of institutional change. Journal of Evolutionary Economics, vol. 13, no 3, pp. 289-317.

BMBF (2012) Mit Foresight in die Zukunft schauen, Berlin: BMBF. Available at https://www.bmbf.de/de/mit-foresightin-die-zukunft-schauen-930.html, accessed 04.12.2018.

Cambridge (2018) Foresight in the Cambridge Dictionary. Available at https://dictionary.cambridge.org/dictionary/ english/foresight, accessed 04.12.2018.

Chan S. (2001) Complex Adaptive Systems. Paper presented at the ESD.83 R Research Seminar in Engineering Systems, October 31 - November 6, 2001. Available at: http://web.mit.edu/esd.83/www/notebook/Complex\%20 Adaptive\%20Systems.pdf, accessed 04.12.2018.

Chow G.C. (1993) Capital Formation and Economic Growth in China. Quarterly Journal of Economics, vol. 108, no 3, pp. 809-842.

De Long J.B., Summers L.H. (1991) Equipment Investment and Economic Growth. Quarterly Journal of Economics, vol. 106, no 2, pp. 445-502.

Devereux M.B., Lapham B.J. (1994) The Stability of Economic Integration and Endogenous Growth. Quarterly Journal of Economics, vol. 109, no 1, pp. 299-305.

Drexler E. (1986) Engines of Creation: The Coming Era of Nanotechnology, New York: Anchor Books.

Ermolenko G.V., Ermolenko B.V., Proskuryakova L., Fetisova Y. (2017) Wind and solar PV technical potentials: Measurement methodology and assessments for Russia. Energy, vol. 137, pp. 1001-1012.

Foresight Automotive (2018) Implementing innovations \& adding economic value: Interdisciplinary exchange and fruitful networking. Available at: https://foresight-automotive.com/ziele/?lang=en.

Foresight Group (2018) Vision \& Values. Available at https://www.foresightgroup.eu/, accessed 04.12.2018.

Foresight Institute (2018) Advancing beneficial technology. Available at https://foresight.org/\#, accessed 04.12.2018.

Foster A.D., Rosenzweig M.R. (2003) Economic Growth and Rise of Forests. Quarterly Journal of Economics, vol. 118, no 1, pp. 601-637.

Futurezone (2013) Foresight: Den Zukünften auf der Spur. Available at: https://futurezone.at/science/foresight-denzukuenften-auf-der-spur/24.590.988, accessed 04.12.2018.

Galilei G. (2002) Sidereus Nuncius (News about new stars) (reprinted by H. Blumenberg), Frankfurt: Suhrkamp.

Gapminder (2018) Statistical tools. Available at: https://www.gapminder.org/tools/, accessed 04.12.2018.

GEA (2012) Global Energy Assessment - Toward a Sustainable Future, Cambridge (UK) and New York: Cambridge University Press; Laxenburg (AT): International Institute for Applied Systems Analysis.

Grossman G.M., Krueger A.B. (1995) Economic Growth and the Environment. Quarterly Journal of Economics, vol. 110, no 2, pp. 353-377.

Gürgen E., Snoek H., Craig J., McHugh J., Izvorski I., van Rooden J. (2009) Economic Reforms in Kazakhstan, Kyrgyz Republic, Tajikistan, Turkmenistan, and Uzbekistan (Occasional Paper 183), Washington, D.C. International Monetary Fund. Available at: http://www.imf.org/external/pubs/nft/op/183/index.htm, accessed 11.06.2018.

Hanusch H. (ed.) (1988) Evolutionary Economics: Applications of Schumpeter's Ideas, Cambridge, New York, Melbourne: Cambridge University Press.

Heylighen F. (1996) The Growth of Structural and Functional Complexity during Evolution. The Evolution of Complexity (eds. F. Heylighen, D. Aerts), Dordrecht: Kluwer Academic Publishers. Available at http://pespmc1. vub.ac.be/Papers/ComplexityGrowth.html, accessed 04.12.2018.

Hiltunen E. (2006) Was It a Wild Card or Just Our Blindness to Gradual Change? Journal of Futures Studies, vol. 11, no 2, pp. 61-74.

Horx M. (2018) Zukunftsinstitut and Publications. Available at https://www.horx.com/, accessed 04.12.2018.

IIASA, WEC (1998) Global Energy Perspectives in 1998, London: World Energy Council; Laxenburg (AT): International Institute for Applied Systems Analysis.

IMF (2009) Republic of Kazakhstan - Concluding Statement of the IMF Mission, January 16, 2009, Washington, D.C. International Monetary Fund. Available at: http://www.imf.org/external/np/ms/2009/011609.htm, accessed 11.06.2018.

IPCC (2001) Climate Change 2001 (Synthesis Report. A Contribution of Working Groups I, II, and III to the Third Assessment Report of the Intergovernmental Panel on Climate), Cambridge (UK), New York: Cambridge University Press.

IPCC (2002) Special Report on Emissions Scenarios (SRES), Geneva: Intergovernmental Panel on Climate Change. Available at: www.ipcc.ch/pdf/special-reports/spm/sres-en.pdf, accessed 11.06.2018.

IPCC (2014) The Fifth Assessment Report, Geneva: Intergovernmental Panel on Climate Change.

Islam S.M.N., Munasinghe M., Clarke M. (2003) Making long-term economic growth more sustainable: Evaluating the costs and benefits. Ecological Economics, vol. 47, no 2-3, pp. 150-166.

Jones C.I. (1995) Time Series Tests of Endogenous Growth Models. Quarterly Journal of Economics, vol. 110, no 2, pp. 495-525. 
Jones C.I., Williams J.C. (1998) Measuring the Social Return to R\&D. Quarterly Journal of Economics, vol. 113, no 4, pp. 1119-1135.

Knizhnikov A. (2018) WWF Rating 2018: Results, Progresses, Challenges regarding environmental responsibility in the Russian oil \& gas industry. Paper presented at the Ecological Responsibility in Russia’s Energy Sector Workshop, 5th December 2018, Berlin.

Korotayev A., Zinkina J. (2014) On the structure of the present-day convergence. Campus-Wide Information Systems, vol. 31, no 2/3, pp. 139-152.

Landes D.S. (2000) The Wealth and Poverty of Nations: Why Some Are So Rich and Some So Poor, New York: W.W. Norton.

Lovelock J. (1988) The Ages of Gaia. A Biography of Our Living Earth, New York, London: W. W. Norton \& Co.

Meadows D.H., Randers J.; Meadows D.L., Behrens W.W. (1972) The Limits to Growth: A Report for the Club of Rome's Project on the Predicament of Mankind, New York: Universe Books.

Mehrabanfar E. (2014) Wild Cards Applications in Futures Studies. International Journal of Modern Management e Foresight, vol. 1, no 8, pp. 212-218.

Nikolova B. (2017) The wild card event: Discursive, epistemic and practical aspects of uncertainty being 'tamed'. Time \& Society, vol. 26, no 1, pp. 52-69. DOI: 10.1177/0961463X15577283.

Ofer G. (1987) Soviet Economic Growth. Journal of Economic Literature, vol. 25, no 4, pp. 1767-1833.

Öttl U.F.J., Pichler B., Schultze-Naumburg J., Wadispointner S. (2014) Integration policies in Europe - a web-based search for consensus. Campus-Wide Information Systems, vol. 31, no 2/3, pp. 121-138.

Proskuryakova L., Kovalev A. (2015) Measuring energy efficiency: Is energy intensity a good evidence base? Applied Energy, no 138, pp. 450-459. DOI: 10.1016/j.apenergy.2014.10.060.

Rivera L.A., Romer P.M. (1991) Economic Integration and Endogenous Growth. Quarterly Journal of Economics, vol. 106, no 2, pp. 531-555.

Rivera L.A., Romer P.M. (1994) Economic Integration and Endogenous Growth - An Addendum. Quarterly Journal of Economics, vol. 109, no 1, pp. 307-308.

Rosa E.A., Dietz T. (2012) Human drivers of national greenhouse-gas emissions. Nature Climate Change, vol. 2, pp. 581-586. DOI:10.1038/nclimate1506.

Schipper L., Unander F., Marie-Lilliu C. (2000) The IEA Energy Indicators: Understanding the Energy-Emissions Link, Paris: International Energy Agency. Available at: http://s3.amazonaws.com/zanran_storage/www.iea.org/ ContentPages/26167538.pdf, accessed 06.07.2018.

Schmitz A. (2003) Elitenwandel und politische Dynamik in Kasachstan (SWP-Studie 39/2003), Berlin: Die Stiftung Wissenschaft und Politik (SWP). Available at: http://www.swp-berlin.org/common/get_document.php?asset_ $\mathrm{id}=179$, accessed 06.07.2018.

Schmitz A. (2009) Kasachstan: neue Führungsmacht im postsowjetischen Raum? (SWP-Studie 2009/S07), Berlin: Deutsches Institut für Internationale Politik und Sicherheit. Available at: https://www.swp-berlin.org/fileadmin/ contents/products/studien/2009_S07_smz_ks.pdf, accessed 06.07.2018.

Steinmüller K. (2012) Wild Cards, Schwache Signale und Web-Seismographen. Focus Jahrbuch 2012 (ed. W.J. Koschnick), pp. 1-26. ISBN 9783981088793.

Sterman J. (2000) Business Dynamics: Systems Thinking and Modeling for a Complex World, New York: McGraw Hill.

Vester F. (1980) Sensitivitätsmodell, Frankfurt-am-Main: Regionale Planungsgemeinschaft Untermain.

Walsh C.L., Glendinning S., Castán-Broto V., Dewberry E., Powell M. (2015) Are wildcard events on infrastructure systems opportunities for transformational change? Futures, vol. 67, pp. 1-10. Available at: https://doi.org/10.1016/j. futures.2015.01.005, accessed 04.12.2018.

WEC (2003) Drivers of the Energy Scene, London: World Energy Council. Available at: http://www.worldenergy.org/ publications/315.asp, accessed 06.07.2018.

WNA (2018) Uranium and Nuclear Power in Kazakhstan, London: World Nuclear Association. Available at: http://www.world-nuclear.org/information-library/country-profiles/countries-g-n/kazakhstan.aspx, accessed 06.11 .2018

Z_Punkt (1986) Was wir für Sie tun können. Available at http://www.Z-punkt.de/de/profil, accessed 04.12.2018. 